\title{
Implementation of participatory forest management in Kerala, India
}

\author{
Misa MASUda ${ }^{1)}$, Junichi MishiBa ${ }^{2)}$ and Maheshwar DHAKAL ${ }^{3)}$ \\ ${ }^{1)}$ Graduate School of Life and Environmental Sciences, University of Tsukuba \\ ${ }^{2}$ Friends of the Earth, Japan \\ ${ }^{3)}$ Master's Program in Environmental Sciences, University of Tsukuba
}

\begin{abstract}
Joint Forest Management was introduced as an innovative method to realize sustainable forest utilization in India. Since the central government issued the first Joint Forest Management guideline in 1990, it has been accepted by the state governments and also supported by local communities. In the state of Kerala, $28.9 \%$ of the land is maintained as forests, despite a high population density. Research on the livelihoods of local people and the role of Participatory Forest Management (Joint Forest Management in Kerala), is expected to benefit other regions with similar conditions. Since information on the forests in Kerala is not sufficient, firstly we outlined the Participatory Forest Management programs and the implementation process, and secondly selected a program and conducted in-depth interviews of 40 households. The results of this study indicate that the guidelines of the central government were duly modified to meet the local conditions. The local stakeholders were well organized to implement Participatory Forest Management. Rehabilitation activities were completed smoothly at the initial stage, but after that the process was stalled. Pressures on forest resources were originally not so serious and agroforestry on farmlands is common so it seems difficult to maintain the activities and enthusiasm of the participants. As a result, incorporating some measures for local communities to an earn income through forest management is recommended. Using non-forest land tree crops for firewood is another alternative solution to forest issues.
\end{abstract}

Key words: India, Kerala, Joint Forest Management, Participatory Forest Management, forest utilization

\section{INTRODUCTION}

There are strong correlations between high-poverty areas and forested areas in India. Population and poverty are the two main causes of destructive pressure on forests (Ahmed, 1997). Almost one fifth of the Indian population is considered to be partially or wholly dependent on forest resources for their livelihoods. The people living in and around the forests consume forest products for firewood, fodder and timber to fulfill their basic needs. Nevertheless, Indian forest cover was almost unchanged from 63.93 million ha (19.5\% to the total land area) in 1991 to 63.73 million ha (19.4\%) in 1999 (Forest Survey of India, 2001), and according to the Global Forest Resources Assessment 2000 by FAO, it slightly increased compared to 1990 (FAO, 2001).

In the past, most of India's forest policies were developed to meet industrial and commercial demands for producing and maximizing revenue, while ignoring local needs (Sarin, 1996). Though most of the recorded forests were national forests, each state government managed forests and collected the revenue. However, the $42^{\text {nd }}$ amendment of the constitution in 1976 shifted the management of forests and wildlife from the state to the Union and the states (Nagamine, 2002). The latest Forest Policy issued in 1988 admitted that excluding local communities in forest management, use of forest lands for non-forestry purposes without ensuring compensation, and the tendency to treat forests as revenue earning resources, were the major reasons for the failure of the forest management practices in the past. This second Forest Policy, proclaimed after independence, is called the New Forest Policy, and it strongly emphasized the necessity to address the quality of life of the 350 million people living in and around the forests (Bahuguna, 2002). One of the measures called for Joint Forest Management (JFM) to become the impetus for changing the conventional approach to that of one prioritizing environmental stability and the welfare of local communities (Pari, 1998).

JFM was formally circulated to all state governments and union territories in 1990 as a resolution of the central government, and sixteen state governments immediately issued their acceptance of the JFM resolution (Sarin, 1996). As was expected, the JFM programs have had positive results, because people have a stake in the outputs (Hill \& Shields 1998). After a decade of field experiences and feedback from the stakeholders concerned, the JFM guidelines for 2000 and 2002 have been prepared and issued for further betterment of forests and in order to institutionalize local communities in the forest management activities. The JFM Cell and the JFM Unit were created under the Ministry of 
Environment and Forests (MoEF) at the national level to monitor and coordinate JFM activities.

The area covered by JFM has increased, reaching 10,250,000 ha in 2000, 14,095,360 ha in 2002 (Damodaran, 2003), and 17,331,955 ha in 2003 (MoEF, 2004). The JFM area in 2003 accounted for $22.6 \%$ of the total recorded forests in 2001 (Forest Survey of India, 2001), but at the state level there was large variation in progress. While the forest area managed under JFM accounted for $57.8 \%$ of the total recorded forests in Madhya Pradesh, $50.9 \%$ in West Bengal, and 48.0 \% in Chhattisgarth, there were five states with less than $5 \%$ and, by 2003, Meghalaya had not yet adopted JFM.

\section{METHODS}

Community based forest management (CBFM) programs are still under trial in Southeast Asia, and the broad experiences of JFM in India can be studied and learned from. Kumar and Kant (2005) included JFM as a category of $\mathrm{CBFM}$, and tried to find the limiting factors for CBFM with respect to the performance of forest agencies. Based on their analysis of questionnaires distributed to foresters of four selected states in India, they concluded that there was a negative correlation between organizational bureaucracy and acceptability of CBFM systems. On the other hand, Misra and Kant (2004) studied the economic, social, and biological output of JFM using explanatory variables, such as heterogeneity and dependency of the user groups, gender issues, and village leadership, for their case study in Gujarat state, and they found balancing economic output and social output difficult.

These two discussions suggest it is necessary to study the issue on different levels. In the case of India, whether JFM is introduced or not is primarily determined by political decisions at the state government level, though the indicators of success are at the local-level, such as the area and the number of participants (Fig. 1). The study by Kumar and Kant (2005) focused on the interactive relationship between the Indian Forest Service (IFS) of MoEF and the forest departments of the state governments, which are relatively homogeneous organizations controlled by IFS. The focus of Misra and Kant (2004) is the performance of JFM at the local level, and they admitted a limitation in applying the results to regions with different conditions.

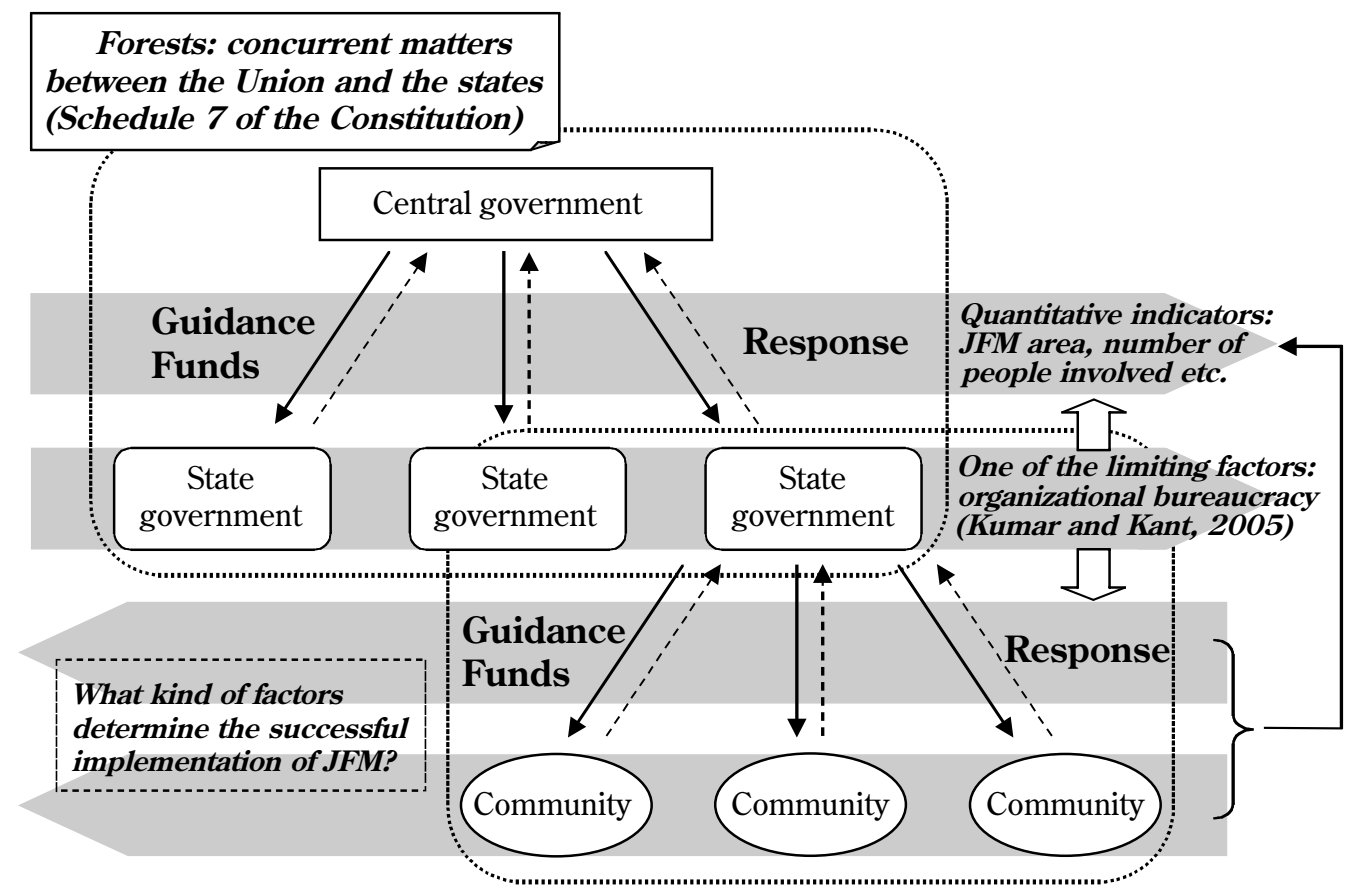

Fig. 1. Relationship of the Union and the state governments at the implementation of JFM

Our concern is on finding the presuppositions to introduce JFM on the state level and local responses at the initial stage of implementation. The study site Kerala is located on the southwestern tip of India. We selected Kerala, because it has a humid climate similar to Southeast Asia and it adopted JFM relatively late compared to other states. In Kerala JFM was introduced in 1998 with a synonym of Participatory Forest Management (PFM). Hereafter the term JFM is 
applied to the national level discussions and PFM is used in the context of Kerala.

First we focused on the sequential process of implementation from the government to local communities, and duly interviewed the key informants of Kerala Forest and Wildlife Department (KFD). Next, we selected a PFM program in Randukai to study, because it has been in existence longer than others. From the list of participants, 45 households were extracted by stratified sampling method, whose details are described subsequently. Interviews with these respondents were carried out using structured questionnaires prepared in English and translated to Malayalam, the official language of Kerala state. Since the goal of the local-level interviews was to examine the sustainability of the PFM program through the differences in responses derived from a wide range socio-economic status, we applied structural analysis and compared the difference of dependency on forest resources and motivations.

The primary data collection was carried out from September to November 2002 and a supplemental visit was made in February 2004.

\section{RESULTS}

\section{General description of Kerala :}

Kerala is a long, narrow state with a great north-south length of $580 \mathrm{~km}$. It can be divided into three topographical regions: lowland along the long stretch of coastal line, adjoining upland, and the Western Ghat Mountains that form the natural boundary with the states of Tamil Nadu and Karnataka. Randukai is located on the hilly upland area in the middle part of the state (Fig. 2).

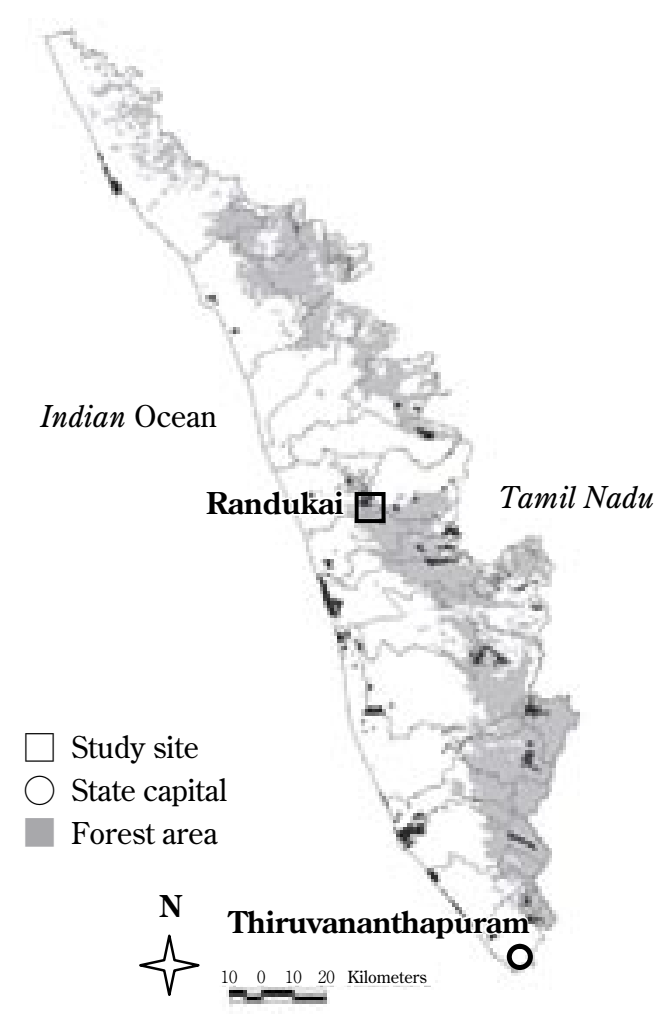

Source: Kerala Forest and Wildlife department, 2004

Fig. 2. Distribution of forests in Kerala and location of the study site

The average annual rainfall from 1984 to 1993 was $2181 \mathrm{~mm}$ (Kerala State Land Use Board, 1995). It was nearly 5000 $\mathrm{mm}$ along the coast and western border of the Wayanad Plateau, but gradually declined toward the inland to $1500 \mathrm{~mm}$ or less (French Institute of Pondicherry, 2003). A variety of forest vegetation from wet to semi-arid results from such a large difference in rainfall; Kerala is famous for evergreen forests, bamboos and palms (Chundamannil, 1993).

The population density is 819 people $\mathrm{km}^{-2}$, which is more than two times greater than the national average of 324 people $\mathrm{km}^{-2}$ in 2001 (Datta \& Sundharam 2004). Around $74 \%$ of the population still live in rural areas (Forest Survey of 
India, 2001). Most of the population speak Malayalam. Tribal people, $1.1 \%$ of the total population in 2001 (ibid.), mainly live in forested regions and some are still inside reserved forests.

Before independence, most of the southern part was not directly ruled by the colonial government, but was controlled by the Maharaja of Travancore-Cochin United Kingdom, while the northern part formed Malabar district under the Madras Presidency. When the Forest Act was first enforced in 1878, the Madras Presidency objected, due to the potential for plantation development, particularly in the Western Ghat. It was finally settled with the establishment of the Madras Forest Act in 1882, but forestland demarcation did not yet begin (Ribbentrop, 1900). In addition, the long existence of princely states and separate administration after independence, delayed establishing any uniform forest administration and management system in Kerala. These areas were transferred to the states of Travancore and Cochin, and the Malabar district of the state of Madras after independence (Kerala Gazetteers Department, 1989; Vasudevan and Sujatha, 2001).

The current jurisdiction of Kerala state was created in 1956 by combining these three regions. Nevertheless, the enforcement of a series of land and forest related acts, Kerala Forest Act in 1961, Kerala Land Reform Act in 1963, and Kerala Private Forests (Vesting and Assignment) Act in 1971, brought about great progress in the establishment of the state forest (Masuda and Mishiba, 2003). Now, all of the state forests in Kerala have already been classified as reserved forests (1,103,800 ha) and protected forests (18,300 ha). The total forestland of 1,122,100 ha accounts for $28.9 \%$ of the state land (Forest Survey of India, 2001).

The reserved forests in Kerala are managed under a highly stratified organization of the KFD (Fig. 3). 8,500 people are employed under the KFD to support this complicated organization (KFD, 2002).

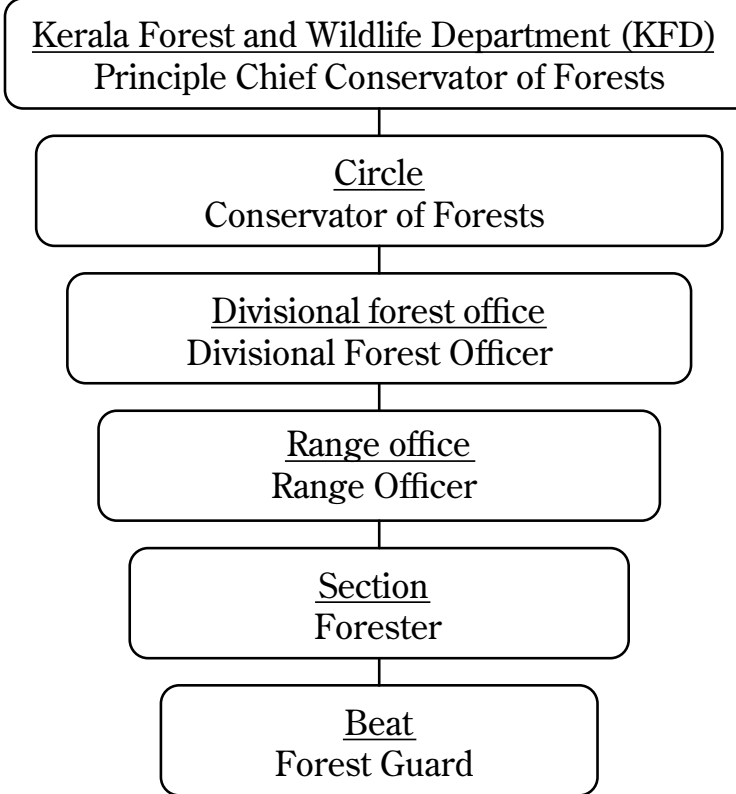

Source: KFD, 2002

Fig. 3. Forest management organization in Kerala

\section{Development of PFM in Kerala :}

\section{Outline of the PFM programs}

While JFM expanded to many states in the early 1990s, in Kerala the PFM guideline was established later in 1998. The reasons behind the delay are not be explored in this study, but the financial support of the World Bank triggered its rapid progress. After the proclamation of the PFM guideline, it has been observed that both local people's livelihoods and the forests' conditions have improved (French Institute of Pondicherry, 2003).

According to an internal document provided by the KFD in 2002, the PFM program in Kerala consists of three models: Fringe model, Non-Timber Forest Products (NTFP) model, and a separate model for the Cardamom Hills 
Reserve. The difference between the Fringe and NTFP models is that the former involves the population outside forests, while the latter is applied to the tribal minorities still living inside the forests and making their livelihood by NTFP collection (Fig. 4).

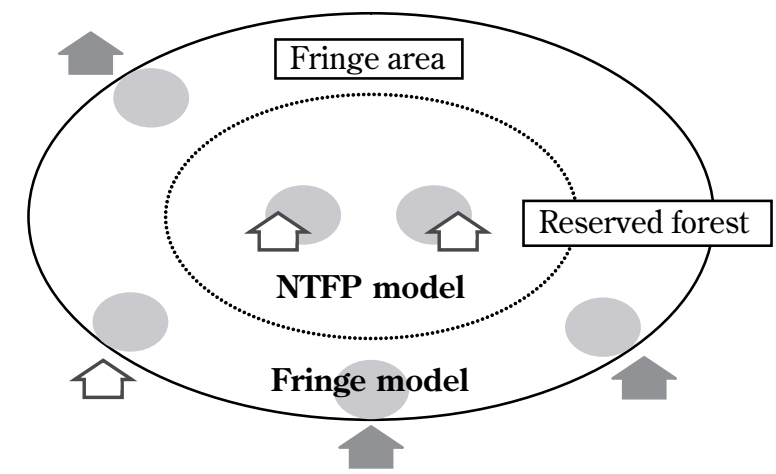

Settlement of non-tribal people

Settlement of tribal people

The area managed by VSS

Source: interview at KFD in 2002

Fig. 4. Scheme of Fringe model and NTFP model

The implementation body of PFM is called Vana Samrakshana Samithi (VSS), which means forest conservation committee in Sanskrit. The development of PFM occurs in five stages: initial (2 months), preparation ( 2 months), planning (4 months), implementation (40 months), and monitoring stage (60 months). During the initial stage, local people are organized in a VSS by the KFD. The VSS is expected to establish a micro-plan under its own initiative and, after approval of the plan, make a contract with the KFD to maintain and manage a certain area of forest. The outline of the Fringe model is as follows:

* The maximum area to be transferred to a VSS is 300 hectares of reserve forests.

* Each VSS is in charge of the core fund, credibility fund for office work, and operational fund for activities, which are provided by the KFD based on the allocated forest area and the number of VSS members, and will be in the custody of forest officers at a divisional level.

* Each VSS can sell NTFP from the allocated reserve forest or fine forest offenders, and can add the revenue to the core fund, together with other subsidies.

As per the guidelines of the JFM program, at least $33 \%$ of the total executive members of the VSS must be women. A VSS is led by a locally nominated president and an officially appointed secretary, who is generally the forester of the section concerned. The president and secretary are expected to coordinate the government programs for local communities through VSS members. To keep the records of revenue and expenditures of the VSS, a separate post, treasurer, is appointed. The executive members of VSS are normally selected from different parts of society considering gender, castes, tribal groups, geographical representation and so on.

Since the beginning of PFM in Kerala, the formation and implementation of VSS have continuously increased (Fig. 5). As of October 2003, 366 Fringe VSS were already formed, consisting of approximately 187,504 people from 46,033 households. On average, 126 households are organized into one VSS.

\section{Organization and activities of the Randukai VSS}

Randukai does not refer to a particular administrative jurisdiction. The area consists of a ward and part of another ward of the Thrissur district.

According to the oral history of the respondents, the area around Randukai had been covered by forests until the 1940's and, except a few tribal people, uninhabited. Most of the current population gradually migrated from different 


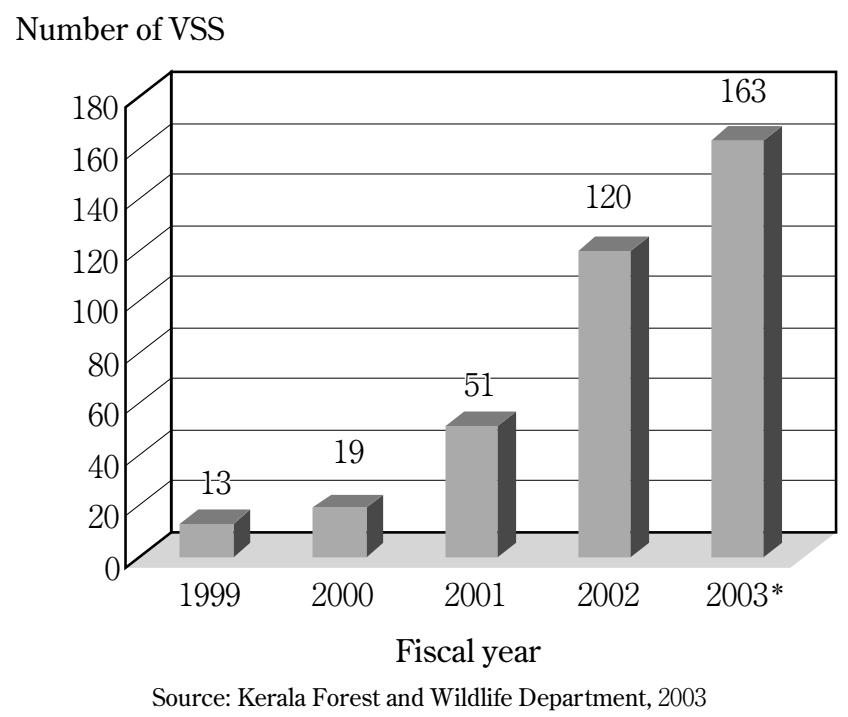

Fig. 5. Yearly increase of Fringe VSS in Kerala. The data for $2003^{*}$ is January through October.

parts of the state, first as logging workers employed by the government. Now the area is developing into a suburb, and it is easy to access by bus or other means of land transportation. The nearest city, Chalakudy, is located approximately 100 $\mathrm{km}$ from Kochi, the business center of Kerala.

The Randukai VSS formed in 2000 and started activities in 2001, after their five-year micro plan had been approved by the KFD. Altogether, 373 people from 223 households were organized into the VSS, and 193 hectares of a reserved forest of around 500 ha were allocated to the VSS. The settlement where the VSS members reside is located in between this reserved forest and a 1,630 ha teak (Tectona grandis) plantation established by the KFD from 1953 to 1982 . The forest land has already been demarcated and stone signs called jhanda are arranged on the main corners of the boundary.

According to the guideline, an NGO or NGI (non-governmental individual) should be appointed and employed by the KFD as an intermediary between a VSS and the KFD. In the case of Randukai, a university student was employed as the NGI, and the president of VSS, also a local person, has a master's degree. Though Randukai consists of both tribal and non-tribal people, no tribal people were organized to the Randukai VSS. They utilized another part of the reserved forest and were allowed to sell the NTFP.

Main activities of the Randukai VSS included: constructing sheeting to fight soil erosion, planting trees on patches of open land inside the allocated area, and patrolling. At the time of our primary data collection in 2002, construction and planting work had already been completed, and the remaining routine activities were patrolling and meeting. The former was carried out by the group of the Forest Protection Gang whose members were appointed by the VSS. The work was compensated at the beginning, but later left unpaid due to lack of funds. Routine meetings of the executive body were held every month and the general meetings for all VSS members were held twice a year.

\section{Details of interviewed households :}

\section{Sampling method and an outline of interviewed households}

The members of the Randukai VSS were categorized into four socio-economic groups by wealth ranking, which was accomplished by a local NGO with the initiative of the KFD in 2001 . To categorize the members, they adopted the following indicators representing socio-economic status and gave a point to each:

* Homeless, including roofless

* Without latrine

* Absence of drinking water facilities, or any type of water facilities farther than $150 \mathrm{~m}$ from the house

* More than two daughters under 18 years of age

* Without dependents 
* Illiterate

* Malnutrition, less than two meals a day

* Only one household earner

* Alcoholic

* Determined scheduled caste or tribal affiliation

Based on the sum of points, the 223 member households were ranked as either wealthy (0-1), ordinary (2-3), poor (4), or below the poverty line (5 points and above). In this study, around $20 \%$, on an average, were randomly selected from each rank, which is hereafter referred to as rich, middle, poor, and very poor. Of the 45 sample households thus chosen, five were ultimately omitted due to their frequent or long absence. Though overall the average land area of each rank corresponds closely to status, (2.03 ha for the rich, 0.67 for the middle, 0.15 ha for the poor, and 0.03 ha for the very poor), there were two cases where this was not true. Consequently, one household initially categorized as rich that had less land area than the average of the middle group, was reallocated to the middle group and vice versa, so final designations resulted in three sample households for the rich, 19 for the middle, 13 for the poor, and five for the very poor group (Table 1).

Table 1. Total number of sample households, and averages of age, household members, and land area by wealth ranking (Oct. 2002). Five sample households of the middle rank (*) could not be interviewed due to their absence at every time of visit.

\begin{tabular}{|c|c|c|c|c|c|}
\hline Household & Rich & Middle & Poor & Very poor & Total \\
\hline Total no. of households & 14 & 120 & 67 & 22 & 223 \\
\hline $\begin{array}{l}\text { No. of sample households } \\
\text { (\% to total) }\end{array}$ & $\begin{array}{c}3 \\
(21.4)\end{array}$ & $\begin{array}{c}19<24^{*} \\
(15.8)\end{array}$ & $\begin{array}{c}13 \\
(19.4)\end{array}$ & $\begin{array}{c}5 \\
(22.7)\end{array}$ & $\begin{array}{l}40<45 \\
(17.9)\end{array}$ \\
\hline Average age of $\mathrm{HH}$ heads & 46.0 & 43.6 & 46.0 & 42.8 & 44.5 \\
\hline Average no. of $\mathrm{HH}$ members & 6.0 & 4.8 & 3.8 & 3.0 & 4.4 \\
\hline Average land area (ha) & 2.53 & 0.59 & 0.15 & 0.03 & 0.53 \\
\hline
\end{tabular}

Source: Randukai VSS and field survey in 2002

There is no significant difference in the average age of the household heads ( $\mathrm{p}=0.86$ by variance analysis). However, this does not always mean that there was no bias of the life cycle, as a significant difference is observed in the average number of household members. This difference can be explained by the historical background of this area, where forest clearance took place relatively recently, after the Grow More Food Campaign in 1943. In regard to the origin of the land, 16 households migrated from adjacent regions and acquired land by clearance, while 22 were from outside the district and acquired land by purchase. The people of the rich group belong to the former pioneers and have maintained an extended family system on their plantations. The relatively small average size of the very poor group is because this category included a widow without children.

\section{Farming system}

Kerala is one of the major cash crop producing states in India. The trend of decreasing farm sizes and fragmentation, however, resulted in a declining importance of the agricultural sector. Along with urbanization along the coastal line, a dramatic shift from annual staple crops to perennial non-staple crops occurred (FAO, 1985). Once occupying large areas, food crops such as rice and cassava that were developed under the Grow More Food Campaign after the famine in 1943, decreased and were replaced with perennial crops such as coconut, rubber, and banana (George, 2001).

The land use pattern in Randukai also reflects these tendencies. According to the oral history of the sample households, wet paddy was once cultivated in Randukai. Those paddy fields have already been converted to dry fields and the main crops are perennial, such as rubber, coconut, areca nut, and banana. Under, or in between, the rows of perennial crops, annual cash crops, such as beans, ginger, turmeric, cassava, and pineapples, are grown. Such agroforestry practices are commonly found all over the state. 
Despite the small size of land tenancy, income from spice crops is adequate in Randukai. People who cultivate spices can sell them at the local markets for quick returns.

\section{Sources of income}

Of the sample households, $15 \%$ made their living by farming only, and approximately $85 \%$ of the households had other sources of income, such as physical wage work, carpentry, tailoring, shop keeping, and migrant work. At the time of our interviews, there were three household members working abroad in Sri Lanka, Saudi Arabia, and Mauritania.

Due to owning a large area of the land, agricultural income was higher among the richer people. The correlation coefficient is 0.83 for the land area and agricultural net income, and 0.71 for the land area and total income. The ratio of the average net agricultural income to the total income is $85.3 \%$ for the rich, $54.4 \%$ for the middle, and $49.5 \%$ for the poor group. The relatively high dependency of the very poor group on agricultural income, $68.8 \%$, was derived from agricultural wage work, tenantry, and cattle rearing. The household heads of this group had various disadvantages, such as ill health and/or scheduled caste family background. One relatively recently migrated from Tamil Nadu. As expected, the average income of each group also corresponds well to their wealth ranking (Table 2).

Table 2. Average of annual net cash income (Oct. 2001-Sep. 2002). One sample household of very poor group (*), a widow who gained her living by supports of relatives, is excluded.

Unit: Rupees (1 US\$ = 47 Rs)

\begin{tabular}{cccccc}
\hline Average & Rich & Middle & Poor & Very poor* & Total \\
\hline Land area (ha) & 2.53 & 0.59 & 0.15 & 0.03 & 0.53 \\
\hline $\begin{array}{c}\text { Agricultural income } \\
\text { (\%) }\end{array}$ & 92,697 & 20,956 & 12,090 & 11,888 & 22,024 \\
Non-agric. income & $(85.3)$ & $(54.4)$ & $(49.5)$ & $(68.8)$ & $(61.0)$ \\
(\%) & 16,000 & 17,589 & 12,338 & 5,400 & 14,105 \\
Total & $(14.7)$ & $(45.6)$ & $(50.5)$ & $(31.2)$ & $(39.0)$ \\
(\%) & 108,697 & 38,545 & 24,429 & 17,288 & 36,129 \\
& $(100.0)$ & $(100.0)$ & $(100.0)$ & $(100.0)$ & $(100.0)$ \\
\hline
\end{tabular}

Source: Field survey in 2002

\section{Dependency of local community on forest resources and the role of PFM : Utilization of forest resources}

There was no change in NTFP collection before or after participation in PFM. Almost one third of the total interviewed households obtained their firewood mainly from farmland outside forests and two households used no firewood in the preceding year. When every temporary use of firewood is taken into consideration, dependency on forest resources was highest among the people of the poor group. In regard to the very poor group, two sample households acquired firewood from farmland owned by their relatives or where they engaged in agricultural wage work. In addition to the natural forest allocated to the VSS, the teak plantation was also a good source of firewood (Fig. 6).

Distance determined where firewood was collected. Since the settlement and farmland are located in between the PFM allotment and the teak plantation, people either collected at the PFM forest or the plantation, depending on which was closest. No household utilized both areas for firewood collection. It seems the first priority was given to the farmland, and the PFM allotment and teak plantation supported the landless people. The average farmland area is 1.01 ha for those who mainly collected firewood from farmland ( 15 households, excluding two tenants of the very poor group), and 0.25 ha for those who collected from the PFM allotment and teak plantation (23 households). Propane gas and kerosene were used as supplements to firewood.

Among the 26 households who engaged in firewood collection more than once a week, 19 households (73.1\%) mainly collected it from the PFM allotment or teak plantation, while 7 (26.9\%) from private farmland (Fig. 7).

Buying and selling firewood was undertaken by households in the middle group and the very poor group, but it was not common in this area and, according to the regulations, only tribal people were allowed to sell firewood. One of the 


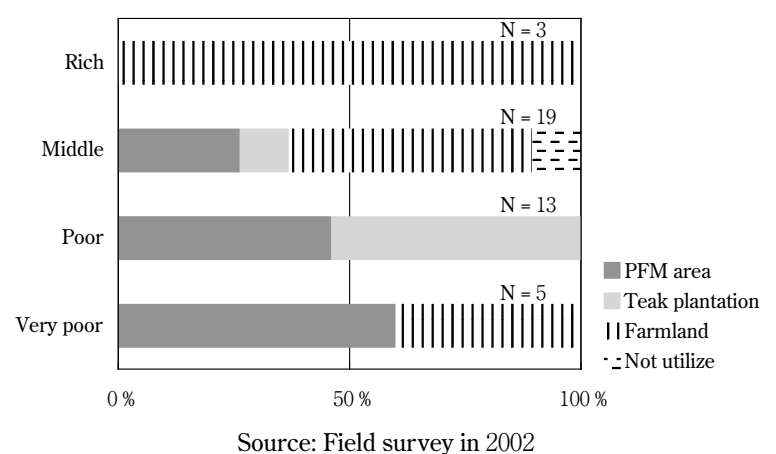

Fig. 6. Main localities of firewood collection (Oct. 2001-Sep. 2002)

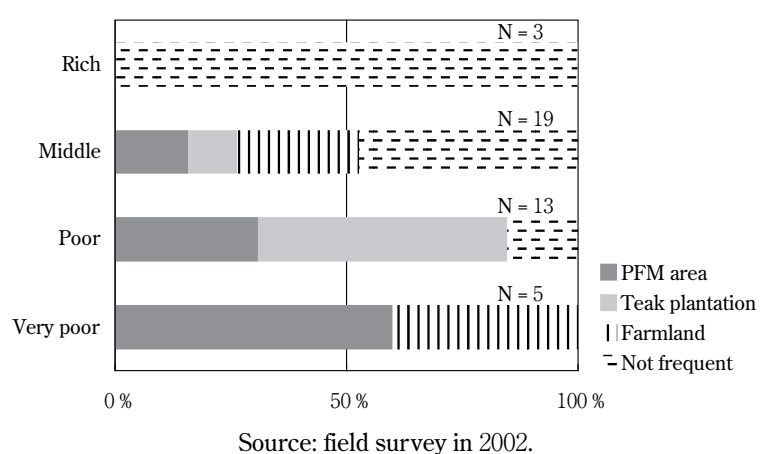

Fig. 7. Main localities of routine firewood collection (Oct. 2001-Sep. 2002). Those who average fewer than once a week are categorized as 'not frequent'.

reasons for the low dependency on firewood among the rich group is that they can obtain it easily from their homestead. Such light work may be done with other daily activities and therefore not recorded as a distinct activity. Another reason could be that firewood collection was done, not by the family members themselves, but by housekeeping servants instead.

The utilization of forests for fodder was less than firewood, because not all the households raised cattle. Among the 40 interviewed households, 19 (47.5 \%) were not in need of fodder and 11 (27.5\%) mainly utilized farmland. Although grazing inside reserved forests is prohibited, it occurred. However, this practice was just occasionally reported at the meetings and not regarded as an offence by the VSS members.

Other necessities collected from the forest were medicinal plants, edible fruits, green manure, and poles. While almost all the households utilized various medicinal plants, only two households answered that they occasionally engaged in wild fruit collection in the preceding year.

\section{Incentives for participating in PFM}

Among the 40 sample households, 11 and three household heads answered that the working opportunities provided by PFM and the authorized right to collect NTFP, respectively, were the main reasons for them to take part in PFM. Besides these households (35.0\% of the total), 10 households (25.0\%) showed their concern for forest conservation and $11(27.5 \%)$ answered that they were prompted to participate. While those who expressed concern about forest issues were mainly from among the richer households, the working opportunity provided by PFM was more important among the poorer groups (Fig. 8).

The frequency of attendance at the general meetings, which had been held twice since the Randukai VSS started the activities until the time of interviews, was highest among the very poor households (Fig. 9).

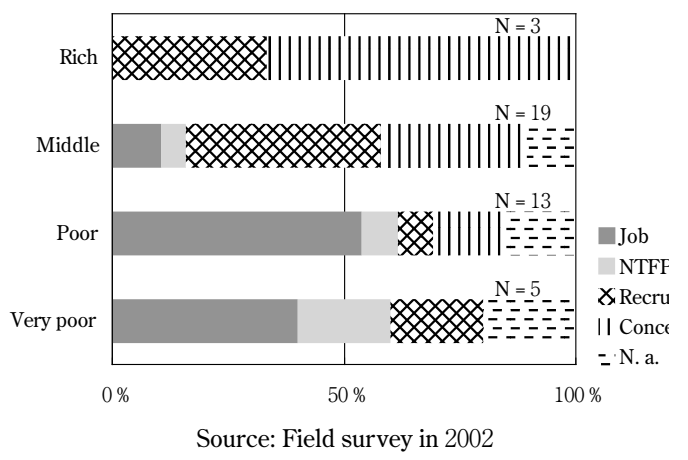

Fig. 8. Main reasons for participating in PFM

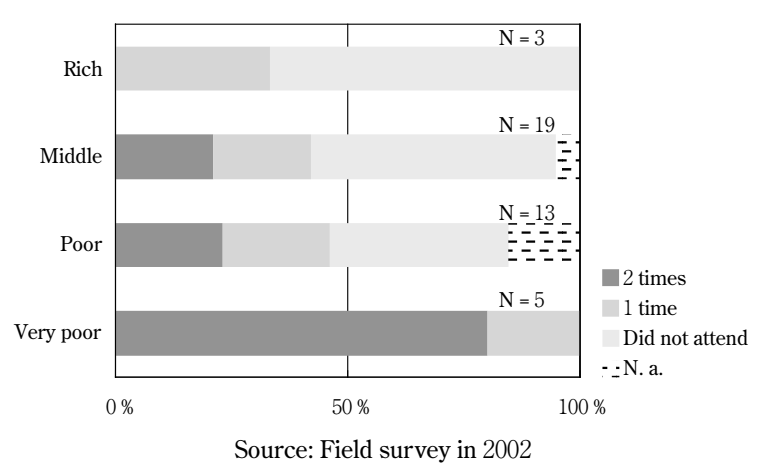

Fig. 9. Frequency of attending the general meetings

According to the Chi Square Test, no relationship was found between the reasons for participating and the frequency of attending the meetings $\left[\chi^{2}=2.2279<\chi^{2}(6,0.05)=12.5916\right]$. However, those who were recruited by 
intermediaries to participate in VSS show a tendency to be reluctant to attend the meetings from the analysis of the standardized residuals.

\section{DISCUSSION AND CONCLUSION}

Unlike the recent political change that took place in Indonesia, which enforced the partial devolution of forest administration from the central to local governments, JFM aims at devolution from the state governments directly to the communities inside and outside forests under the strong initiative of the central government. After trials at regional levels, the central government incorporated this new idea into the forest policy and has encouraged the state governments to adopt it. To what extent the New Forest Policy and JFM guidelines can come into force at the state level is another subject to be studied, but we can still define an effective combination of top-down and bottom-up approaches by studying the process.

Though Kerala accepted JFM later than other states, a "laggard" according to Bahuguna (2002), the KFD immediately took various measures, like trainings and study tours of advanced areas and discussed the ideas of participatory approaches, two of which were embodied as the Fringe model and NTFP model. The area under PFM rapidly expanded and reached $15.2 \%$ of the total recorded forests in 2003.

Not having serious deforestation problems undoubtedly allowed the program to expand rapidly. Despite the high population density, the land use pattern outside the forests contributed to reduction of the dependency on forest resources. Observing from the top of hills, indeed, one could observe bare land only along roads and residential areas. Almost all parts of the state were covered with tree crops. In fact, Kerala means the land of coconut. Such common practices of agroforestry on the farmlands in Kerala naturally decreased daily pressure on forest resources. This suggests that agroforestry could be an alternative to deforestation caused by subsistence activities. In the case of Randukai, various sources of non-agricultural income also helped to reduce the pressure on forests.

As per the instructions of PFM, different stakeholders at the local level were well organized into the VSS. One of the households in the rich category comes from a landlord family that once reigned before the Kerala Land Reform Act was enforced in 1963. However, effects from such involvement of the relatively wealthy class were not clear. They joined the VSS because they were recruited or interested in environmental issues, but they did not seem particularly active or concerned.

By contrast, expectations to generate income through participation in the VSS were apparent among the poorer people. However, the benefits of participation did not always meet their expectations, and the respondents often complained of this at our interviews. Only one interviewed household earned some money by patrolling in the previous year. Late payments by the KFD also discouraged the people and may have deadened the enthusiasm at the beginning.

Although such technical problems were observed, they did not seem to have affected forest resources. The existence of the more valuable teak plantation in good condition without PFM, underscores that the forest department has maintained the resources using a sufficient number of professional staff by so-called conventional forestry. If the goal of PFM is an absolute transfer of forest management to local communities, a process for entrusting the management of plantations should also be taken into considerations. In any case, it seems necessary to take measures to generate income from forest resources. Otherwise, the VSS organization may become an empty formality.

ACKNOWLEDGEMENTS This study was conducted as a part of the Comparative Study on the Trend of Decentralization and Privatization in Forest Management of Developing Countries, and was financially supported by the Japan Society for Promotion of Sciences (No. 13372005). During the field study, we were supported by the people of Randukai, particularly Mr. and Mrs. Varghese Elevankudiyil, Mr. Vincent Pullockaran, and Mr. Sajeev Kumar. The KFD and the Kerala Forest Research Institute provided us with a more than adequate facility. We would like to extend our sincere thanks to these people and organizations for their invaluable cooperation.

\section{REFERENCES}

Ahmed, M. F., 1997. In-depth country study: India. FAO Regional Office for Asia and the Pacific, Bangkok.

Bahuguna, V. K., 2002. Forest policy initiatives in India over the last few years. In Proceeding of the Forest Policy 
Workshop 22-24 January, 2002, Kuala Lumpur.

Chundamannil, M., 1993. The history of forest management in Kerala. Kerala Forest Research Institute, Peechi.

Damodaran, D., 2003. Joint Forest Management in India: assessment of performance and evaluation of impacts. N. p., Bangalore.

Datta, R. \& Sundharam, K. P. M, 2004. Indian economy. S. Chand \& Company, New Delhi.

FAO, 1985. Intensive multiple-use forest management in the tropics: analysis of case studies from India, Africa, Latin America and the Caribbean. FAO, Rome.

FAO, 2001. Global forest resources assessment: main report. FAO, Rome.

Forest Survey of India, 2001. State of forest report 2001. Forest Survey of India, Dehra Dun.

French Institute of Pondicherry, 2003. A brief outline of biodiversity conservation strategy and action plan for Kerala. KFD, Thiruvananthapuram.

George, P. S., 2001. Population and land use in Kerala. In Indian National Science Academy et al (eds.), Growing populations, changing landscapes: studies from India, China and the United States. Washington D. C.

Hill, I. \& Shields, D. 1998. Incentives for Joint Forest Management in India: analytical methods and case studies. World Bank, Washington D.C.

KFD, 2002. Green citadel: an interactive CD-ROM on forests of Kerala. KFD, Thiruvananthapuram.

Kerala Gazetteers Department, 1989. Kerala Government gazetteers, vol. 3. Government of Kerala, Trivandrum.

Kerala State Land Use Board, 1995. Land resources of Kerala State. Kerala State Land Use Board, Thiruvananthapuram.

Kumar, S. \& Kant, S., 2005. Bureaucracy and new management paradigms: modeling foresters' perceptions regarding community-based forest management in India. Forest Policy and Economics 7: 651-669.

Masuda, M. \& Mishiba, J., 2003. Creation of forest reserves and change of the role in India (in Japanese). Bulletin of Tsukuba University Forests 19: 1-40.

MoEF, 2004. Annual report 2003-2004. MoEF, New Delhi.

Misra, D. \& Kant, S., 2004. Production analysis of collaborative forest management using an example of joint forest management from Gujarat, India. Forest Policy and Economics 6: 301-320.

Nagamine, R., 2002. Forest policy after the independence (in Japanese). In H. Yanagisawa (ed.), Modern South Asia: development and environment. University of Tokyo Press, Tokyo.

Pari, B., 1998. The persistence of population in Indian forest policy. The Journal of Peasant Studies 5: 96-123.

Ribbentrop, B., 1900. Forestry in British India. Government Priniting, Calcutta.

Sarin, M., 1996. Joint Forest Management: the Himalayan experience. Centre for Environment Education, Ahmedabad.

Vasudevan, C. V. \& Sujatha, V., 2001. Forest laws of Kerala. Ganesh Publications, Kochi.

Received $7^{\text {th }}$ Mar. 2005

Accepted 21 ${ }^{\text {st }}$ Apr. 2005 